\title{
PENERAPAN METODE MIND MAPPING PADA MODEL DIRECT INSTRUCTION UNTUK MENINGKATKAN KEMAMPUAN PEMECAHAN MASALAH FISIKA SISWA SMPN 16 MATARAM
}

\author{
Rika Venisari ${ }^{1}$, Gunawan ${ }^{2}$, Sutrio $^{3}$ \\ Program Studi Pendidikan Fisika \\ Universitas Mataram \\ Mataram, Indonesia \\ Email: rikavenisari@gmail.com
}

\begin{abstract}
The purpose of research is to improving problem solving skill of physics at student in SMPN 16 Mataram used mind mapping method at direct instruction model. Subyek research is VIII-E class with 32 students. The type of research is Classroom Action Research which done 2 cycle which consist of planning phase, execution, observation, evaluation, and reflection. Student and teacher activity data were get from observation sheet, and students learning result were get from test in the end of each cycle. Efficacy indicator of this research is if the category activity student is active and be improve, learning result of students is complete clasicality, which students get score $\geq$ KKM value 75 have reached $\geq 85 \%$ from student grand total following evaluation. The result of this research showing the student activity and learning result is improved. In first cycle got mean score activity student is 10,5 with category active enough, and class mean is 73.6 with clasical complete $65.6 \%$. In second cycle got mean score activity student is 13,5 with category active, and mean class is 80.9 with complete classical is $87.5 \%$. Based on the results got from each cycle, it can be concluded that the implementation of mind mapping method on direct instruction model can increase the physics problem solving skill of student of SMPN 16 Mataram, specially in vibration and wave chapter.
\end{abstract}

Keywords: Mind Mapping, Direct Instruction, Problem Solving Skill

\section{Pendahuluan}

Sains berkaitan dengan cara mencari tahu tentang alam secara sistematis, sehingga sains bukan hanya penguasaan kumpulan pengetahuan yang berupa fakta-fakta, konsep-konsep, atau prinsip-prinsip saja tetapi juga merupakan suatu proses penemuan. Pendidikan sains di sekolah menengah diharapkan dapat menjadi wahana bagi siswa untuk mempelajari diri sendiri dan alam sekitar, serta prospek pengembangan lebih lanjut dalam menerapkannya dikehidupan sehari-hari. Pendidikan sains menekankan pada pemberian pengalaman langsung untuk mengembangkan kompetensi agar siswa mampu menjelajahi dan memahami alam sekitar secara ilmiah [1].

Mata pelajaran fisika adalah salah satu mata pelajaran dalam rumpun sains yang erat kaitannya dengan dunia teknologi dan pembangunan. Selain turut menyumbang terciptanya teknologi baru, melalui pembelajaran fisika juga mampu menumbuhkan nilai-nilai positif diantaranya melatih berpikir logis dan analitis; melatih ketelitian dan berpikir kritis; melatih sikap hati-hati; teratur dan jujur; dan sebagainya [2].
Berdasarkan hasil observasi peneliti dan hasil wawancara dari guru bidang studi IPA terhadap siswa kelas VIII-E SMPN 16 Mataram diperoleh informasi bahwa masih banyak siswa yang terlihat kurang aktif dalam mengikuti proses pembelajaran, sebagian siswa sulit menghapalkan konsep-konsep fisika sehingga siswa sulit memahami materi fisika tertentu. Hal ini disebabkan kurangnya daya serap siswa dan aktivitas membaca yang rendah. Ini juga diperburuk adanya beberapa siswa yang tidak mencatat materi pelajaran atau setelah mencatat tidak membuka atau jarang membaca catatannya kembali. Hal ini juga didasari masih adanya kebiasaan siswa mencatat dengan memindahkan atau menyalin catatan yang ada kedalam buku mereka dan juga sistem berpikir siswa yang belum teratur. Gejala inilah dikatakan siswa pasif, karena belajar dengan menghapalkan kalimat lengkap tidak akan efektif, disamping bahasa yang digunakan menggunakan gaya bahasa penulis. Sehingga pada pertemuan berikutnya, disaat guru memberikan pertanyaan kepada siswa, ada yang terlihat kebingungan, dan ada juga yang belum mampu menjawab, bahkan ada yang memberi jawaban yang kurang relevan dengan pertanyaan yang diajukan guru. Kondisi ini terjadi saat digunakan metode tanya jawab hanya sebagian siswa 
yang mampu dan mau bertanya serta menjawab, demikian juga pada saat pemberian tugas masih banyak dijumpai siswa yang apabila ditanya kembali secara lisan, siswa sudah tidak dapat mengungkapkan kembali jawaban yang ditulisnya. Keadaan ini menunjukkan kemampuan pemecahan masalah yang rendah dikalangan siswa. Hal itu ditunjukkan dari hasil ujian yang masih rendah.

Atas dasar masalah yang dikemukakan diatas diperlukan inovasi pembelajaran berbeda yaitu dengan metode peta pikiran atau mind mapping. Dengan mind map siswa tidak perlu fokus untuk mencatat secara keseluruhan, siswa hanya mengetahui inti masalah, kemudian membuat peta pikiran sesuai kreativitasnya sendiri. Salah satu model pembelajaran yang tepat untuk media tersebut adalah direct instruction, karena direct instruction dapat menunjang proses belajar siswa yang berkaitan dengan pengetahuan prosedural yang terstruktur dengan baik yang dapat diajarkan secara bertahap.

\section{TinjaUAn PUSTAKa}

\section{A. Metode Mind Mapping}

Konsep mind mapping asal mulanya diperkenalkan oleh Tony Buzan tahun 1970-an. Metode ini dikenal juga dengan nama radiant thinking. Mind mapping merupakan metode penyusunan catatan demi membantu siswa menggunakan seluruh potensi otak agar optimum. Caranya, menggabungkan kerja otak bagian kiri dan kanan. Dengan metode mind mapping siswa dapat meningkatkan daya ingat hingga $78 \%$.

Peta pikiran merupakan suatu teknik grafik yang sangat ampuh dan menjadi kunci yang universal untuk membuka potensi dari seluruh otak, karena menggunakan seluruh keterampilan yang terdapat pada bagian neo-korteks dari otak atau yang lebih dikenal sebagai otak kiri dan otak kanan. Menurut peneliti sendiri mind mapping adalah cara mencatat yang kreatif, efektif dan menyenangkan karena menggunakan simbol dan warna dalam memetakan pikiran yang sesuai dengan kerja otak [3].

Mind map berperan pada otak anak untuk melihat gambaran-gambaran yang telah mereka kenal (sebuah gambar bernilai ribuan kata) serta asosiasi dan berbagai hubungan yang mereka buat tanpa dibatasi oleh aturan tata bahasa dan sematik. Mind map seketika memberikan gambaran menyeluruh kepada anak, sekaligus memberikan kesempatan baginya untuk menghimpun hal-hal yang terkait lebih erat satu sama lain. Mind map bagi anak-anak merupakan alat menakjubkan yang bisa memberi mereka kesempatan untuk membuka diri dan menjelajahi ruang-ruang memori, pemahaman, pemikiran kreatif, analisis, persiapan untuk tugas sekolah, tinjauan dan ekspresi diri [4].

\section{B. Model Direct Instruction}

Pembelajaran langsung adalah salah satu pendekatan mengajar yang dirancang khusus untuk menunjang proses belajar siswa yang berkaitan dengan pengetahuan deklaratif dan pengetahuan procedural yang terstruktur dengan baik yang dapat diajarkan dengan pola kegiatan bertahap, selangkah demi selangkah[5].

Dengan adanya direct instruction diharapkan dapat memotivasi siswa untuk mempelajari fisika sehingga materi bisa dikuasai dengan baik dan dapat meningkatkan hasil belajar. Manfaat direct instruction bagi siswa ialah siswa langsung dapat melihat memegang dan mengamati objek secara langsung. Dengan siswa melihat, memegang dan mengamati objek secara langsung maka siswa akan lebih paham dan mengerti tujuan pembelajaran yang hendak dicapai.

\section{Kemampuan Pemecahan Masalah}

Kemampuan memecahkan masalah adalah kemampuan kognitif tingkat tinggi, tahap berpikir pemecahan masalah setelah tahap evaluasi yang menjadi bagian dari tahapan kognitif Bloom. Hal ini menunjukkan bahwa kemampuan memecahkan masalah adalah kemampuan kognitif tingkat tinggi. Pemecahan masalah merupakan bagian dari kurikulum fisika yang sangat penting karena dalam proses pembelajaran maupun penyelesaiannya, siswa dimungkinkan memperoleh pengalaman menggunakan pengetahuan serta keterampilan yang sudah dimiliki untuk diterapkan pada pemecahan masalah[6].

[7]Langkah-langkah pokok dalam pemecahan masalah fisika, sebagai berikut:

1) Analisis Soal

Tujuan analisis soal adalah untuk memahami soal secara keseluruhan melalui identifikasi dan interpretasi informasi-informasi penting yang diberikan serta jika diperlukan mengubahnya menjadi bentuk yang mempermudah langkah-langkah penyelesaian.

2) Penyusunan konstruksi penyelesaian

Strategi cukup efektif untuk menyusun konstruksi penyelesaian suatu soal adalah membagi atau mengurai menjadi bagian-bagian 
soal yang lebih kecil dan lebih sederhana yang disebut sub-sub soal.

3) Pemeriksaan solusi

Langkah ini sangat penting untuk memastikan apakah solusi yang diperoleh benar dan memuaskan. Apabila ternyata ditemukan kekurangan ataupun kesalahan dapat segera diperbaiki.

\section{METODE PENELITIAN}

Jenis penelitian ini adalah penelitian tindakan kelas (clasroom action research). Penelitian tindakan kelas adalah bagaimana sekelompok guru dapat mengorganisasikan kondisi praktik pembelajaran mereka, dan belajar dari pengalaman mereka sendiri. Subyek penelitian dalam penelitian ini adalah siswa kelas VIII-E dan objek pada penelitian tindakan ini adalah berbagai kegiatan yang terjadi di dalam kelas selama berlangsungnya proses belajar mengajar. Penelitian dimulai dari penetapan judul bulan Oktober 2013 dan selesai bulan Mei 2014 bertempat di SMPN 16 Mataram.

Prosedur dan langkah-langkah yang digunakan dalam melaksanakan penelitian mengikuti model yang dikembangkan oleh Kemmis dan Mc Taggart yaitu model spiral. Model Kemmis dan Mc Taggart pada hakekatnya berupa perangkat-perangkat atau untaian dengan satu perangkat terdiri dari empat komponen yaitu: rencana tindakan (planning), tindakan (actimg), pengamatan (observing), dan refleksi (reflecting). Keempat komponen yang berupa untaian tersebut dipandang sebagai satu siklus [8].

Teknik pengumpulan data pada penelitian ini adalah tes hasil belajar, lembar observasi aktivitas guru, lembar observasi aktivitas siswa dan lembar angket respon siswa. Data tes hasil belajar diperoleh dengan menggunakan instrumen yang telah diuji validitasnya dan reliabilitas. Analisis validitas instrumen menggunakan rumus product moment untuk uji validitas soal dan K.R 20 untuk uji reliabilitas soal.

\section{Hasil dan Pembahasan}

Pembelajaran pada penelitian tindakan kelas ini, dilaksanakan dalam dua siklus dengan menerapkan metode mind mapping pada model direct instruction untuk meningkatkan kemampuan pemecahan masalah fisika siswa SMPN 16 Mataram.. Materi yang dipelajari adalah getaran dan gelombang. Perbandingan hasil belajar pada siklus I dan siklus II dapat dilihat pada tabel 1 .
Tabel 1. Hasil Belajar Siswa pada Siklus I dan Siklus II

\begin{tabular}{lcc}
\hline \multirow{2}{*}{ Kategori } & \multicolumn{2}{c}{ Siklus } \\
\cline { 2 - 3 } & I & II \\
\hline Nilai Tertinggi & 88,2 & 94,4 \\
Nilai Terendah & 41,2 & 61,1 \\
Jumlah siswa yang mengikuti & 32 & 32 \\
evaluasi & 73,6 & 80,9 \\
Rata-rata kelas & 21 & 28 \\
Jumlah siswa yang tuntas & 11 & 4 \\
Jumlah siswa yang tidak tuntas & $65,6 \%$ & $87,5 \%$ \\
Ketuntasan klasikal & & \\
\hline
\end{tabular}

Hasil analisis evaluasi hasil belajar siswa siklus I diperoleh nilai rata-rata kelas sebesar 73,6 dengan ketuntasan klasikal 65,6 \% dari 32 orang siswa atau masih terdapat 11 orang siswa yang belum mencapai nilai KKM. Hasil ini menunjukkan bahwa hasil belajar siswa belum mencapai indikator keberhasilan karena ketuntasan secara klasikal masih berada di bawah $85 \%$ dari seluruh siswa kelas VIII-E yang berjumlah 32 orang.

Pada siklus I ini soal tes yang diberikan berkaitan dengan subbab materi getaran. Dari penyebaran jawaban siswa (Lampiran 12), terlihat pada soal yang paling banyak dijawab benar adalah adalah soal nomor 3 dan nomor 9. Pada kedua nomor ini hanya 1 (satu) orang yang menjawab salah. Pada soal nomor 3 mengenai pengertian simpangan terbesar, soal ini memang relatif mudah dan nomor 9 mengenai penarikan kesimpulan. Soal nomor 9 termasuk soal kategori tinggi karena berada pada kategori C6, tetapi siswa tidak kesulitan dalam menjawab, karena sebelumnya percobaan pada soal sudah diperagakan sebelumnya oleh guru pada pembahasan materi awal pembelajaran. Sedangkan soal yang paling sulit untuk dijawab adalah soal nomor 15, karena dari 32 siswa hanya 13 siswa yang mampu menjawab benar. Soal ini berada pada tingkat $\mathrm{C} 5$, yang memang membutuhkan pemahaman dalam mengevaluasi soal.

Setelah melakukan kegiatan penelitian pada siklus II diperoleh data hasil belajar siswa mengalami peningkatan yakni nilai rata-rata 80,9 dengan ketuntasan klasikal $87,5 \%$ dari 32 orang siswa atau masih terdapat 4 orang siswa yang belum mencapai nilai KKM. Masih adanya siswa yang tidak tuntas pada siklus II ini dikarenakan ketidakseriusan siswa selama proses pembelajaran, khususnya pada proses pembuatan mind map. Beberapa siswa masih mengandalkan teman kelompoknya dalam membuat mind map maupun mengerjakan LKS yang dibagikan. 
Sehingga hasil pembelajaran yang didapatkan kurang maksimal.

Pada siklus II ini soal tes yang diberikan berkaitan dengan subbab materi gelombang. Dari penyebaran jawaban siswa (Lampiran 13), terlihat pada soal yang paling banyak dijawab benar adalah adalah soal nomor 5, nomor 12 dan nomor 17. Pada kedua nomor ini hanya 1 (satu) orang yang menjawab salah. Pada soal nomor 5 mengenai bentuk gambar transversal dan gambar longitudinal, siswa tidak kesulitan karena gambar mengenai bentuk gelombang ini sudah dijelaskan oleh guru dengan menggambarkannya dipapan tulis. Pada soal nomor 12 mengenai panjang gelombang dan 17 mengenai cepat rambat gelombang, sebagian besar siswa mampu menjawab karena soal ini yang dijadikan contoh soal oleh guru pada saat penjelasan materi. Soal yang paling dianggap sulit adalah soal nomor nomor 10, karena dari 32 siswa hanya 14 siswa yang mampu menjawab benar. Soal ini berada pada tingkat $\mathrm{C} 1$. Banyak siswa yang salah dalam menjawab soal ini dikarenakan kesalahan guru dalam memberikan informasi saat awal pembelajaran.

Jika dibandingkan dengan hasil belajar fisika siswa sebelumnya, yakni dari data nilai ujian semester ganjil, nilai rata-rata siswa kelas VIII-E adalah 61,60. Dengan penerapan metode mind mapping, hasil belajar fisika siswa mengalami peningkatan selama dilakukan penelitian tindakan kelas ini. Jika hasil belajar meningkat, hal itu dikarenakan kemampuan pemecahan masalah siswa sudah meningkat. Dengan demikian, penerapan metode mind mapping pada model direct instruction dapat meningkatkan kemampuan pemecahan masalah fisika siswa SMPN 16 Mataram, khususnya kelas VIII-E.

Untuk data aktivitas belajar siswa pada siklus I dan siklus II dapat dilihat pada gambar 2.

Tabel 2 Aktivitas Belajar Siswa pada Siklus I dan Siklus II

\begin{tabular}{lcc}
\hline \multirow{2}{*}{ Kategori } & \multicolumn{2}{c}{ Skor } \\
\cline { 2 - 3 } & Siklus I & Siklus II \\
\hline Kelompok I & $55 \%$ & $65 \%$ \\
Kelompok II & $60 \%$ & $75 \%$ \\
Kelompok III & $55 \%$ & $70 \%$ \\
Kelompok IV & $50 \%$ & $70 \%$ \\
Kelompok V & $50 \%$ & $60 \%$ \\
Kelompok VI & $45 \%$ & $65 \%$ \\
Skor Total & 63 & 81 \\
\hline \multicolumn{1}{c}{ Skor Rata-Rata } & 10.5 & 13.5 \\
Aktivitas Belajar & Cukup & Aktif \\
Kriteria Aktivitas & Aktif & \\
\multicolumn{2}{c}{ Belajar } & \multicolumn{2}{c}{} \\
\hline
\end{tabular}

Untuk rata-rata aktivitas belajar siswa sebesar 10,5 yang berada pada kategori cukup aktif., Aktivitas belajar siswa sudah memenuhi indikator keberhasilan karena nilainya berada pada kategori cukup aktif. Hasil belajar dan aktivitas belajar siswa tersebut tidak terlepas dari proses pembelajaran yang dilakukan oleh peneliti di kelas.

Aktivitas siswa belum dikatakan aktif pada siklus I ini dikarenakan siswa sangat antusias berlatih membuat mind map sehingga mereka melakukan perilaku yang tidak sesuai dengan katagori, dimana perilaku ini berupa meminjam alat tulis, bertanya ke teman sebangku atau teman samping kanan kiri sehingga mengganggu teman. Hal ini menyebabkan mereka tidak fokus dan kurang menguasai materi pelajaran getaran sehingga mereka terlihat kurang aktif dalam menanggapi pertanyaan yang dilontarkan oleh guru dan hanya sedikit siswa yang mengajukan pertanyaan kepada guru dan aktivitasnya masih cukup pasif. Untuk hasil penilaian mind map sebagian siswa masih kurang mengerti meletakkan topik ditengah dan cara membuat cabang, siswa masih membuat garis lurus bukan berupa cabang, dan berkreasi dalam pembuatan mind map masih rendah.

Maka pada siklus II diberikan perlakuan dan motivasi untuk meningkatkan aktivitas siswa. Disini guru lebih memfokuskan memberi materi pelajaran dengan menggunakan teknik mind mapping secara skematis. Guru memfokuskan interaksi tanya jawab antara guru dan siswa, dan juga interaksi antara siswa dan siswa lainnya dengan melaksanakan persentasi yang oleh beberapa siswa untuk meningkatkan pemahaman, sehingga siswa lebih antusias mendengarkan penjelasan guru dalam menerima pelajaran dan lebih aktif dalam menanggapi pertanyaan yang dilontarkan oleh guru atau siswa lainnya, dan tidak sedikit pula siswa yang menjawab secara serempak atau beramai-ramai saat guru melontarkan pertanyaan. Untuk peningkatan hasil mind map guru menjelaskan kriteria penilaian dari mind map, sehingga siswa termotivasi untuk mendapatkan nilai yang bagus dalam membuat mind map dan pada pelajaran sebelumnya guru memberitahukan siswa untuk membawa alat tulis lengakap dan referensi mengenai materi gelombang.

Untuk rata-rata aktivitas belajar siswa mengalami peningkatan yakni 13,7 dengan kriteria aktif. Dari hasil tersebut, terlihat bahwa hasil belajar siswa sudah mencapai indikator keberhasilan karena ketuntasan secara klasikal telah mencapai $85 \%$ dari seluruh siswa kelas VIII-E. 
Disamping itu kunci keberhasilan pembelajaran di kelas terletak pada kemampuan profesional guru dalam mengelola pembelajaran. Meskipun tujuan pembelajaran dapat direncanakan bersama oleh guru dan siswa, namun pengelolaan pembelajaran lebih berpusat pada guru. Sistem perencanaan dan pengelolaan pembelajaran yang baik akan menjamin terjadinya proses belajar yang efektif pada siswa.

Perencanaan dan pengelolaan pembelajaran yang baik oleh guru tentunya akan membantu guru untuk lebih mengarahkan kemampuan siswa dalam menyelsaikan masalah. Melalui model direct instruction dengan menggunakan metode mind mapping yang dapat dijadikan alternatif dalam pembelajaran fisika, khususnya pada sub materi pokok getaran dan gelombang. Dari hasil penelitian ini secara deskriptif telah menunjukkan bahwa kegiatan pembelajaran yang telah dirancang mampu mengaktifkan siswa dalam sebuah pembelajaran dan membantu pemecahan masalah siswa.

Hasil belajar dan aktivitas belajar siswa tersebut dipengaruhi oleh proses pembelajaran dengan penerapan metode mind mapping pada model direct instruction untuk meningkatkan kemampuan pemecahan masalah fisika siswa yang diterapkan oleh guru. Dari hasil observasi yang dilakukan oleh pengamat (guru mata pelajaran IPA kelas VIII) terhadap aktivitas guru dalam melaksanakan proses pembelajaran pada setiap siklusnya termasuk dalam kategori sangat baik. Skor aktivitas guru pada siklus I dan siklus II ditunjukkan pada tabel 3.

Tabel 3 Aktivitas Guru Pada Siklus I dan Siklus II

\begin{tabular}{ccc}
\hline Siklus & Persentase Skor & Kriteria \\
\hline I & $90 \%$ & Sangat Baik \\
II & $100 \%$ & Sangat Baik \\
\hline
\end{tabular}

Kegiatan guru selama pelaksanaan pembelajaran siklus I diamati oleh pengamat dengan panduan lembar observasi peneliti siklus I yang menunjukkan skor aktivitas peneliti sebesar 18 yang berada pada kategori sangat baik. Dan siklus II aktivitas guru menunjukkan hasil skor sebesar 20 yang berada pada kategori sangat baik. Adanya peningkatan hasil belajar dan aktivitas belajar siswa serta tercapainya indikator keberhasilan pada siklus II, maka penelitian ini dihentikan sampai pada siklus II.

Hal ini menunjukkan, bahwa aktivitas pembelajaran yang dilakukan oleh guru di siklus II sudah optimal sesuai RPP yang direncanakan. Semua langkah dilaksanakan guru, hanya saja kenyataannya di lapangan bahwa kegiatan tersebut kurang dalam pengalokasian waktu pada saat membuat mind map kemudian menyajikan kedepan hasil mind map yang telah dibuat siswa. Sehingga kurang efektif dalam pembelajaran yang telah direncanakan. Dan kendala lain pada waktu pengamatan langsung yang dilakukan oleh observer. Observer mengamati siswa dengan waktu untuk mengamati interval 2 menit secara bergantian sehingga kemungkinan aktivitas siswa yang diamati tidak dapat teramati secara terperinci setiap 2 menit sekali. Disamping jumlah siswa yang diamati banyak.

Penerapan metode mind mapping juga terbukti meningkatkan respon siswa terhadap pembelajaran fisika. Hal itu terbukti dari tingginya respon positif siswa terhadap metode mind mapping berdasarkan angket yang diberikan diakhir siklus II. Perbandingan jumlah respon siswa terhadap metode mind mapping yang telah diterapkan ditunjukkan oleh gambar.

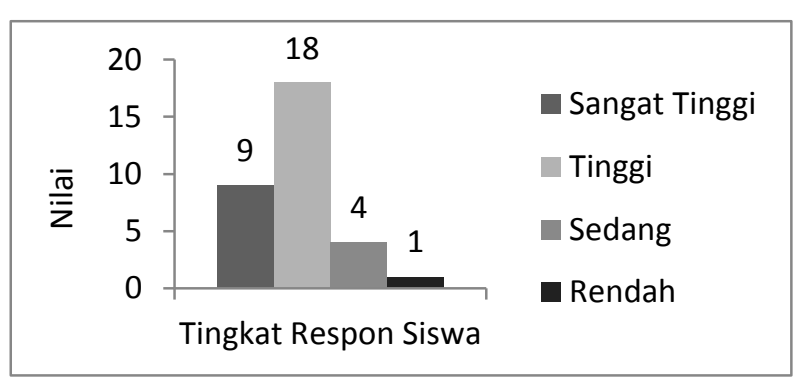

Gambar Perbandingan jumlah respon siswa

Dari gambar terlihat bahwa respon siswa terhadap metode mind mapping paling besar berada pada kategori tinggi. Dari komentar yang didapat siswa tertarik pada mind map karena dapat memfokuskan belajar, lebih berani dalam mengungkapkan pendapat dan sangat bermanfaat dalam pembelajaran fisika karena menyenangkan.

Menurut siswa mind map cukup menarik dan menyenangkan tidak seperti catatan biasa yang mereka buat selama ini. Selain itu mind map mengekspresikan kreatifitas mereka dalam menggambar dan mewarnai sesuai dengan imajinasi mereka, karena dengan selembar kertas yang berisikan gambar, warna, dan simbol dapat mewakili suatu materi pelajaran yang cukup banyak sehingga lebih praktis dan mudah untuk dipahami. Pendapat guru bidang studi IPA juga diperoleh, dimana beliau menyatakan bahwa mind mapping ini sangat menarik dan cocok untuk dilaksanakan dalam pembelajaran khususnya pada siswa SMP, dan siswa SMP masih memiliki rasa ingin tahu yang cukup tinggi dikarenakan mereka masih baru tamat dari SD, 
sehingga mereka lebih antusias mengikuti pelajaran yang menggunakan gambar.

Berdasarkan hasil tersebut, penerapan metode mind mapping dengan model direct instruction dapat menjadikan siswa aktif dalam pembelajaran, khususnya saat berlatih mind map. Hasil penelitian ini menunjukkan bahwa membuat mind map pada kegiatan pembelajaran menjadikan proses keterampilan belajar siswa menjadi terarah, karena siswa mudah mengingat konsep yang penting dari hasil membuat mind map. Hal ini menambah sistem memori bekerja secara aktif dalam mengingat dan memahami materi pelajaran khususnya materi getaran dan gelombang.

\section{Penutup}

Dari hasil penelitian yang telah dilakukan pada siswa kelas VIII-E pada pokok bahasan getaran dan gelombang dapat disimpulkan bahwa enerapan metode mind mapping pada model direct instruction dapat meningkatkan kemampuan pemecahan masalah fisika siswa SMPN 16 Mataram. Pada siklus I, diperoleh rata-rata kelas 73,6 dengan ketuntasan klasikal 65,6\% dan untuk aktivitas siswa diperoleh skor 63 dengan rata-rata 10,5 yang berada pada kategori cukup aktif. Pada siklus II diperoleh rata-rata kelas 80,9 dengan ketuntasan klasikal 87,5\% dan aktivitas siswa diperoleh skor 81 dengan rata-rata 13,5 yang berada pada kategori aktif. Respon ratarata siswa terhadap pembelajaran dengan metode belajar mind mapping adalah tinggi Mereka sangat antusias menggunakan mind map, karena menurut mereka mind map ini menyenangan dan lebih efektif dari catatan biasa yang mereka buat selama ini.

Untuk memperoleh hasil yang lebih baik maka perlu diadakan perbaikan. Misalnya alokasi waktu dapat diatur sebaik mungkin sehingga tiap tahapan pembelajaran dapat berlangsung secara optimal serta mengetahui karakteristik dari siswa, teknik pengelolaan kelas, dan faktor-faktor lain yang berpengaruh terhadap hasil belajar siswa.

\section{UCAPAN TERIMA KASIH}

Terima kasih penulis ucapkan untuk bapak Drs. Mukh.Nazuhi selaku kepala SMPN 16 Mataram serta bapak Chaero Saihu S.Pd selaku guru kelas dan seluruh siswa kelas VIII E tahun pelajaran 2014/2015 yang telah ikut serta dalam penelitian ini.

\section{REFERENSI}

[1] Depdiknas.2003. Kurikulum 2004 Standar Kompetensi Mata Pelajran Fisika Sekolah Menengah Atas dan Madrasah Aliyah. Jakarta: Depdiknas.

[2] Sutrisno.2006. Fisika dan Pembelajarannya. Bandung : Universitas Pendidikan Indonesia.

[3] Astutiamin, (2009), Meningkatkan Hasil Belajar dan Kreativitas Siswa melalui Pembelajaran Berbasis Peta Pikiran (Mind Mapping), http://astutiamin . wordpress.com/2009/11/26/ meningkatkan-hasil-belajar-dan-kreativitassiswa-melalui-pembelajaran-berbasis-petapikiran-mind-mapping/\#more-30 (diakses 20 September 2014)

[4] Buzan, Tony.2007. Buku Pintar Mind Map Untuk Anak. Gramedia Pustaka Utama:Jakarta.

[5] Trianto, (2007), Model - model pembelajaran inovatif beroeientasi konstruktivistik. Prestasi Pustaka: Jakarta.

[6] Sukmadinata dan As'ari. 2006. Pengembangan Kurikilum Berbasis Kompetensi di PT. Bandung : Universitas Pendidikan Indonesia

[7] Mundilarto.2004. Kapita Selekta Pendidikan Fisika. http://staff.uny.ac.id/sites/default (diakses 22 Januari 2015)

[8] Wiriaatmadja, Rochiati.2008. Metode Penelitian Tindakan Kelas untuk Meningkatkan Kinerja Guru dan Dosen. Remaja Rosdakarya:Bandung.

\section{Biografi Penulis}

Rika Venisari, S.Pd, lahir di Pringgasela, 30 November 1992. Tahun 2005 lulus di SDN 2 Labuhan Badas Sumbawa, dan tahun 2008 lulus dari SMPN 1 Labuhan Badas Sumbawa. Tahun 2011 Lulus dari MAN 2 Mataram dan melanjutkan pendidikan S-1 di Universitas Mataram pada program studi pendidikan fisika hingga meraih gelar sarjana tahun 2015. 